\title{
Technical and economic evaluation of different operating modes for mechanized fertilizer application in coffee plantations
}

\author{
Alan Delon Andrade ${ }^{1}$ D , Gabriel Araújo e Silva Ferraz¹ (iD), Rafael de Oliveira Faria1 (D), Murilo Machado de Barros² (D), \\ Fábio Moreira da Silva ${ }^{1}$ iD ${ }^{2}$ Daniele Sarri ${ }^{3}$ iD Marco Vieri $^{3}$ (D)
}

${ }^{1}$ Universidade Federal de Lavras/UFLA, Departamento de Engenharia Agrícola, Lavras, MG, Brasil

${ }^{2}$ Universidade Federal Rural do Rio de Janeiro/UFRRJ, Seropédica, RJ, Brasil

${ }^{3}$ University of Florence, Department of Agricultural, Food, Environment, and Forestry/DAGRI, Florence, Italy

Contact authors: alanmg13@gmail.com, gabriel.ferraz@ufla.br, rafael.ufla@gmail.com, famsilva@ufla.br, egmurilo@yahoo.com.br, daniele.sarri@unifi.it, marco.vieri@unifi.it Received in April 2, 2020 and approved in May 29, 2020

\section{ABSTRACT}

The present study aimed to investigate the performance parameters and related costs of a machinery set composed of a tractor and a machine for fertilizers and soil correctives application, working in a coffee yard. It was evaluated two different operating modes. For the first operating mode (OM1), the machinery applied the total recommended dose to only one side of the plants and traveled in only half of the plot interrows. For the second operating mode (OM2), the machinery applied half the recommended dose to each side of the plants and traveled in all of the plot interrows. The study was performed at Bom Jardim Farm, located in the municipality of Bom Sucesso, state of Minas Gerais, Brazil. The performance parameters included effective field capacity and effective time. The hourly cost of the fertilizers and soil correctives application operation was determined based on the farm's management data and the effective cost was obtained by relating the hourly cost and the effective time. The results showed that OM1 implies higher effective field capacity and lower effective cost, with the cost of only $50.1 \%$ of that found for $\mathrm{OM} 2$.

Key words: Agricultural machinery management; costs; Coffea arabica L.

\section{INTRODUCTION}

Coffee production is prone to risks and uncertainties. Some authors, such as Lombardo et al. (2018) and Bambi et al. (2019), stated that rural areas are facing different and significant challenges. So, rural entrepreneurs investing in coffee production should plan and develop a management system aimed at efficiency and competitiveness while optimizing resources (Lanna; Reis, 2012).

Mechanization has been stepping up in coffee plantations because it increases the operational capacity and decreases production costs (Santinato et al., 2014). Currently, in areas where the ground slope and management system allow the use of machines, all operations performed during the whole crop cycle are mechanized (Cunha; Silva; Dias, 2016). In Brazil, agriculture mechanization is of great importance for cost competitiveness, becoming the second most important production factor, only behind land ownership (Peloia; Milan, 2010). For this reason, small improvements in machinery management may bring higher returns than savings on other production costs (Hunt, 1995).

The study of agricultural operations, which considers field capacity and efficiency, aims to rationalize the use of machinery (Silveira; Yanai; Kurachi, 2006). Information about agricultural machinery performance parameters is of great importance to the management of mechanized agricultural systems, which helps with decision making (Molin et al.,
2006). Field capacity is defined as the amount of work a machine can perform per unit of time. It is an important performance parameter, constituting a measure of the work intensity (Mialhe, 1974).

Cunha, Silva e Dias (2016) studied the mechanized operation of fertilizers and soil correctives application in coffee plantations and observed satisfactory machinery performance parameters. However, machinery performance in coffee plantations depends on the characteristics of the area planted, such as ground slope, plot area and shape, plant conditions and the method or operating mode (Silveira; Yanai; Kurachi, 2006).

In practice, there is no consensus on the correct management and performance of the mechanized operation of fertilizers and soil correctives application in coffee plantations, which depend on the work method used in each farm. In some farms, the fertilizers are applied to both sides of the coffee plants, half of the recommended dose to each side, whereas in others, the total recommended dose is applied to only one side of the coffee plant.

If the application is performed on only one side of the coffee plants, a machine with two sections, i.e., with the ability to apply product on both sides, could apply the whole recommended dose of product to two planting rows simultaneously, eliminating the need to travel into all interrows. This operating mode could result in a significant increase in machinery operational capacity. 
The aim of the present study was to determine performance parameters and carry out an economic analysis of a machinery set, composed of an agricultural tractor and a machine for fertilizers and soil correctives application, by comparing two different operating modes.

\section{MATERIAL AND METHODS}

The study was performed in a coffee plantation that grows the variety Catucaí Amarelo 2SL with an area of 7.5 ha. This plantation was established in 2014 and belonged to Bom Jardim Farm, which was located in the municipality of Bom Sucesso, Minas Gerais $\left(21^{\circ} 01^{\prime} 20^{\prime \prime} \mathrm{S}\right.$ and $\left.44^{\circ} 55^{\prime} 12^{\prime \prime} \mathrm{W}\right)$. Rows were spaced $3.5 \mathrm{~m}$ apart and plants were spaced 0.5 $\mathrm{m}$ apart. The main tracks were $6 \mathrm{~m}$ wide and the secondary track, located at the center of the plot, was $4.5 \mathrm{~m}$ wide. The terrain was flat, and all operations performed in the area were mechanized.

It was used an agricultural John Deere $5075 \mathrm{EF}$ tractor with auxiliary front-wheel drive, a nominal power $55.0 \mathrm{~kW}$ at $2400 \mathrm{rpm}$, a gauge of $1.3 \mathrm{~m}$, a total width of $1.55 \mathrm{~m}$ and a distance between axles of $1.97 \mathrm{~m}$. The tractor was operated in B2 gear, which has average speed of $5.5 \mathrm{Km} \mathrm{h}^{-1}$ at a costsaving engine rotation (1,500 rpm).

The machine for fertilizer and soil correctives application is composed by a regular fertilizer spreader and an electronic system, which enables the application of products at variable rates (Barros et al., 2016). The machine had a load volume of $1.2 \mathrm{~m}^{3}$, a length of $3.36 \mathrm{~m}$, a height of $1.40 \mathrm{~m}$, a gauge of $1.24 \mathrm{~m}$ and a total width of $2.15 \mathrm{~m}$, including the deflectors. The product dispenser mechanism had two independent conveying chains and manually adjusted gates. The machine can, therefore, apply different product doses to each side, as needed. The application rate can be changed by the machine control system, based on a prescription map, or manually using the system's monitor. The distribution mechanism is composed of two horizontal disks. The products application is directed to the planting row by lateral deflectors. The disks are activated individually by hydraulic motors, and the motor speed can be changed through a flow-control valve located in the machine.

The product used was a mix of agricultural lime, serpentinite and agricultural gypsum, at a ratio of 1:1:1 (33.3\% of each compound). The recommended product dose for the area was $1000 \mathrm{~kg} \mathrm{ha}^{-1}$.

Two operating modes of the machinery set were compared. For the first operating mode (OM1), the machine was adjusted to apply the total recommended dose for the area, with the application being performed to only one side of the coffee plants. Because the machine had two sections, the product was applied to two coffee plant rows simultaneously and the machinery set reached only half of the interrows (Figure 1). For the second operating mode (OM2), the machine was adjusted to apply half the recommended dose, applied to both sides of the coffee plants. Thus, the machinery set reached all interrows. To maintain the same headland turn patterns, for OM2, the machinery set skipped one interrow (zig zagged) and then travelled back through the remaining interrows to complete the application, according to the scheme presented in Figure 2.

To avoid the impact of external factors such as changes in terrain and differences in planting row length, three experimental blocks were defined, composed of ten planting rows. The performance parameter data were collected during the machinery set operation in the blocks.

The machinery set trajectory and the effective planting row lengths were recorded using a GNSS (Global Navigation Satellite System) receiver with a maximum error of $3 \mathrm{~m}$ placed on the tractor. The receiver was configured to collect and store data every 5 seconds. The data recorded were organized and analyzed using the GPS TrackMaker $^{\circledR}$ software. The machinery operation time on the planting rows and the time spent with headland turns were measured using a digital chronometer and recorded in field notebooks. Subsequently, the data were transferred to computer worksheets and used to calculate the performance parameters.

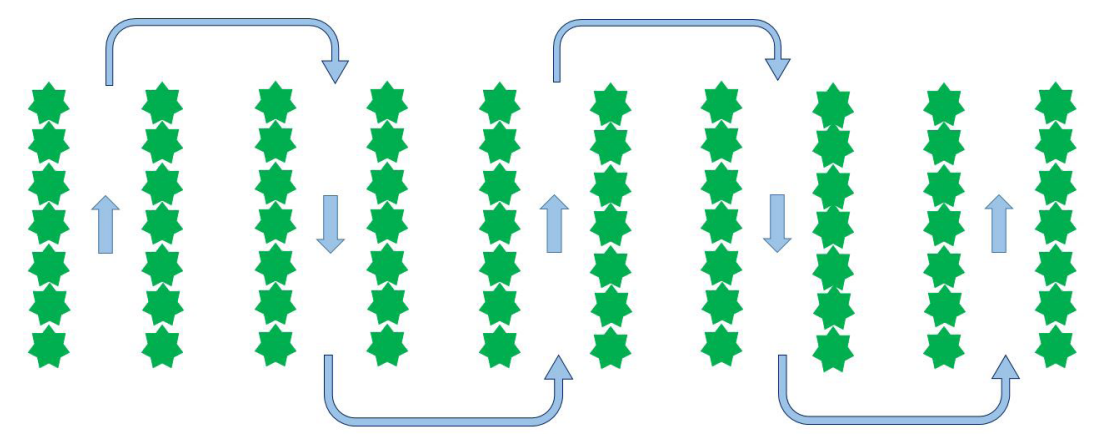

Figure 1: Path of the machinery set for OM1, in which application was performed to only one side of the coffee plants.

Legend: The arrows represent the path of the machinery set and stars represent coffee plants. 


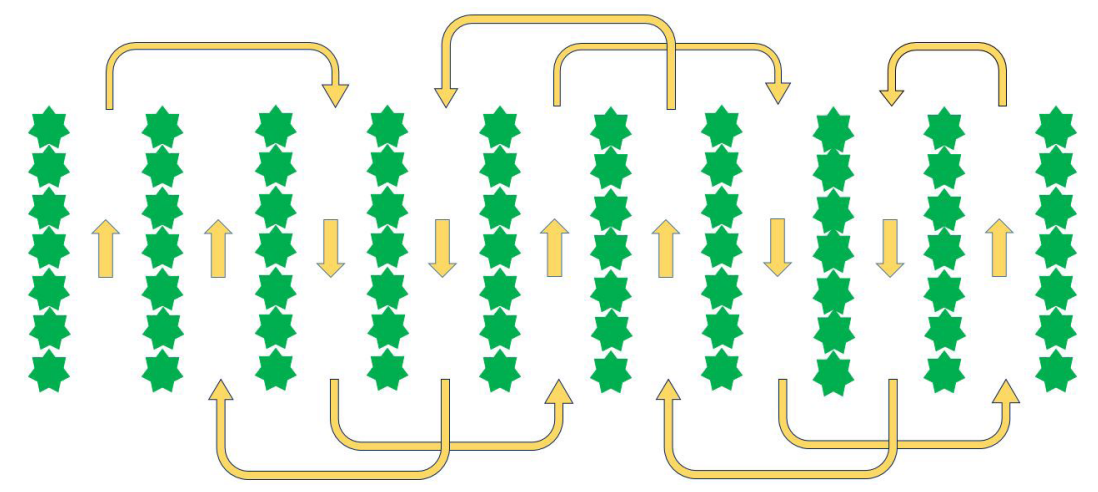

Figure 2: Path of the machinery set for OM2, in which application was performed to both sides of the coffee plants.

Legend: The arrows represent the path of the machinery set and stars represent coffee plants.

The following performance parameters were analyzed: effective field capacity (FCe) and effective time (Te). Effective field capacity was based on the methodology proposed by Mialhe (1974) and calculated using Equation 1:

$\mathrm{FCe}=\left(\frac{\mathrm{W} \times \mathrm{S}}{10}\right)$

where: FCe - Effective field capacity, ha $\mathrm{h}^{-1} ; \mathrm{W}$ - Useful working width, $\mathrm{m}$; $\mathrm{S}$ - Operational speed, $\mathrm{Km} \mathrm{h}^{-1}$.

Operational speed was calculated as the relationship between the effective planting row length and operation time on the row, using Equation 2.

$\mathrm{S}=\frac{1}{\mathrm{t}} \times 3.6$

where: $\mathrm{S}$ - Operational speed, $\mathrm{Km} \mathrm{h}^{-1} ; 1$ - Effective planting row length, $\mathrm{m} ; \mathrm{t}$ - Operation time on row, $\mathrm{s}$.

Effective time is the time needed to perform the operation in a given area, considering only the activities that result in effective work. It can be calculated using Equation 3.

$\mathrm{Te}=\frac{1}{\mathrm{FCe}}$

where: Te - Effective time, $\mathrm{h} \mathrm{ha}^{-1}$; FCe - Effective field capacity, ha $\mathrm{h}^{-1}$.

In addition to the performance parameters, an economic analysis was performed to compare the two operating modes. First, the hourly cost of the fertilizers and soil correctives application operation was determined using methodology adapted by Silva et al. (2013) for coffee plantation conditions. The total hourly cost was calculated using fixed and variable costs. The fixed costs included depreciation, interest, insurance and accommodation, whereas the variable costs included fuel, lubricants, repairs, maintenance and labor. Costs were calculated using data collected in the field and farm management data (Table 1) using computer worksheets.

Table 1: Machinery dataset used to assess the hourly cost.

\begin{tabular}{ccc}
\hline & Tractor & MFSCA \\
\hline Initial value (R\$) & $110,000.00$ & $31,000.00$ \\
Depreciation time (years) & 10 & 5 \\
Interest rate (\% per year) & 7.50 & 7.50 \\
Insurance rate (\% per year) & 1.45 & 1.45 \\
Fuel consumption (liters $\cdot \mathrm{h}^{-1}$ ) & 2.31 & - \\
\hline
\end{tabular}

MFSCA - Machine for fertilizers and soil correctives application.

The operating cost per hectare was calculated for the two operating modes by multiplying the hourly operating cost and the effective operating time. It should be noted that the calculated cost reflects only the expenses culminating in effective work, i.e., the cost of performing the operation in the plot, which in the present study is called the effective cost. Effective cost was calculated using Equation 4.

$\mathrm{C}_{\mathrm{ef}}=\mathrm{C}_{\mathrm{h}} \times \mathrm{Te}$

where: $\mathrm{C}_{\mathrm{ef}}$ - Effective cost, $\mathrm{R} \$ \cdot \mathrm{ha}^{-1} ; \mathrm{C}_{\mathrm{h}}$ - Hourly cost, $\mathrm{R} \$ \cdot \mathrm{h}^{-1}$; Te - Effective time, $h \cdot h a^{-1}$.

\section{RESULTS AND DISCUSSION}

No significant differences in planting row effective length, operation time of the machinery set in the row and operational speed were observed between OM1 and OM2 (Table 2), indicating that the external conditions, which could affect the performance parameters, were uniform for the two treatments. Changes to the performance parameters should, therefore, be due to changes in the operating mode (OM1 or OM2). 
Table 2: Field data.

\begin{tabular}{ccccc}
\hline $\begin{array}{c}\text { Operating } \\
\text { mode }\end{array}$ & $\begin{array}{c}\text { Row length } \\
(\mathrm{m})\end{array}$ & $\begin{array}{c}\text { Maneuver } \\
\text { time }(\mathrm{h})\end{array}$ & $\begin{array}{c}\text { Operation } \\
\text { time }(\mathrm{h})\end{array}$ & $\begin{array}{c}\text { Operation } \\
\text { speed } \\
\left(\mathrm{Km} \cdot \mathrm{h}^{-1}\right)\end{array}$ \\
\hline OM1 & 257.9 & $4.0 \cdot 10^{-3}$ & $4.61 \cdot 10^{-2}$ & 5.6 \\
OM2 & 258.0 & $4.4 \cdot 10^{-3}$ & $4.60 \cdot 10^{-2}$ & 5.6 \\
\hline
\end{tabular}

OM1 - Operating mode with the application to only one side of the coffee plants; OM2 - Operating mode with the application to both sides of the coffee plants.

The average time spent with headland turns was higher for OM2 than for OM1. This was due to the tight maneuvering in $\mathrm{OM} 2$ when the machinery set moved from one interrow to the next (Figure 2), requiring the reversing of the tractor. This maneuver was not necessary for OM1 because the machinery set skipped one interrow in each passage and maneuvers were performed continuously.

The average operation speed was the same for the two operating modes $\left(5.6 \mathrm{Km} \mathrm{h}^{-1}\right)$ and higher than that reported by Silveira, Yanai and Kurachi (2007) as adequate for mechanized operations in coffee plantations (between 3.0 and $4.5 \mathrm{Km} \mathrm{h}^{-1}$ ). However, the speed can vary depending on plantation conditions, interrow width, technical characteristics of the machinery set and type of product applied.

Regarding the machinery set performance parameters (Table 3), the effective field capacity for OM1 was $199.5 \%$ of the value found for OM2. This was expected because in OM1 the product was applied to two planting rows simultaneously, doubling the working width. The useful working width considered for OM1 was $7 \mathrm{~m}$, whereas for OM2 it was $3.5 \mathrm{~m}$.

Table 3: Performance parameters for the machinery set.

\begin{tabular}{ccc}
\hline Operating mode & FCe $\left(\mathrm{ha} \cdot \mathrm{h}^{-1}\right)$ & Te $\left(\mathrm{h} \cdot \mathrm{ha}^{-1}\right)$ \\
\hline OM1 & 3.91 & 0.26 \\
OM2 & 1.96 & 0.51 \\
\hline
\end{tabular}

OM1 - Operating mode with the application to only one side of the coffee plants; OM2 - Operating mode with the application to both sides of the coffee plants; FCe - Effective field capacity; Te - Effective time.

The effective field capacity for OM1 indicates a better use of the productive potential of the machinery, with work performed in less time and using less resources, such as labor and fuel. Some types of fertilizer are volatile and should be applied under environmental conditions favorable to their uptake, resulting in a reduced time frame for the operation. Higher field capacity may therefore result in meeting the nutritional needs of the coffee plants.

The behavior of the effective time was opposite to that of the field capacity, with the effective time of OM1 being $50.1 \%$ of the value of OM2, due to the concept of effective time. The decrease in the operation operating time at a given area benefits crop management because it allows the relocation of labor and machinery to other areas or operations.

The composition of the hourly cost of the fertilizers and soil correctives application operation is presented in Figure 3. The total hourly cost calculated was in accordance with the value found by Cunha et al. (2016) of $50.10 \mathrm{R} \$ \mathrm{~h}^{-1}$. Moreover, these authors observed that fertilizer application presented the lowest hourly cost of all mechanized operations in coffee plantations.

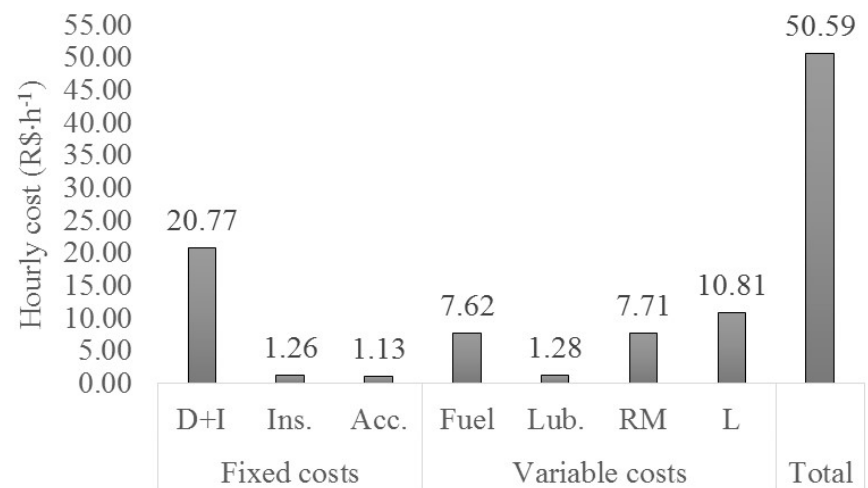

Figure 3: Composition of the hourly cost of fertilizers and soil correctives application.

D+I - Depreciation and interest; Ins. - Insurance; Acc. - Accommodation; Fuel - Fuel; Lub. - Lubricants; RM - Repairs and maintenance; L - Labor.

Among the fixed and variable costs, the machinery depreciation and interest represented the most substantial part of the total hourly cost, and both were calculated together using the method of capital depreciation proposed by Hoji (2006). This was in contrast with Cunha et al. (2016) and Simões, Silva and Fenner (2011), who found that fuel expenses had the most significant impact on operational cost.

The high cost of depreciation and interest may result from the initial values used for the calculation, which were considered the price of new equipment. The decreased fuel cost was due to the tractor model, especially when functioning with lower engine rotations (approximately $1500 \mathrm{rpm}$; "economy rotation"). The average fuel consumption for the fertilizers and soil correctives application operation was 2.31 liters $\mathrm{h}^{-1}$, considering data from all plots in the farm (Table 1).

The effective cost was calculated by multiplying the hourly cost by the effective time (Figure 4). This cost represents the expenses with machinery when operating in the field, considering only the activities that result in effective work.

In practice, farms consider the operational cost, which account for all non-productive costs including travel time, refueling time, operator lunch time, etc. However, the nonproductive time may vary between farms and is affected by operation management factors such as the adoption of mobile 
fueling stations in the field. The effective cost, therefore, allows for the comparison of the two operating modes because the different operating modes directly affect the effective field capacity, which is associated with the performance of the machinery set within the plot.

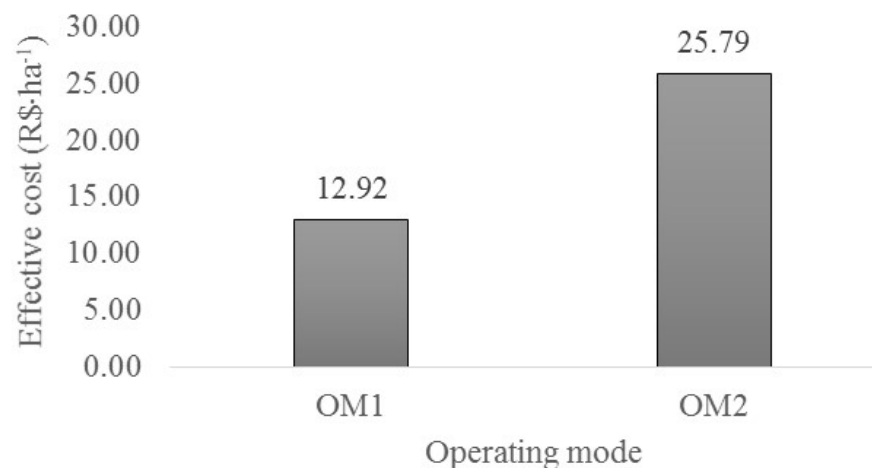

Figure 4: Effective cost for the two operating modes tested.

OM1 - Operating mode with the application to only one side of the coffee plants; OM2 - Operating mode with the application to both sides of the coffee plants.

The effective cost for OM1 was $50.1 \%$ of the value for OM2, which was expected because it is based on the effective time, which presented the same proportion between the two operating modes. The higher working width for OM1 increased the field capacity, and consequently decreased the effective time and the effective cost.

Thus, OM1 presented higher technical and economic viability than OM2 from the point of view of mechanization and contributed to increased performance and decreased operation costs of the fertilizers and soil correctives application. The information presented here can be useful in managing the fertilizers and soil correctives application operation, serving as a reference to assist decision making.

\section{CONCLUSIONS}

Effective field capacity was higher for OM1 than for OM2, whereas effective time showed an opposite trend in the same proportion.

The effective cost followed the trend of the effective time, and the value for OM1 was 50.1\% of the value for OM2. This was due to the higher effective field capacity observed for OM1.

OM1 was the best indicated operating mode because of its higher technical and economic viability when compared to OM2. These data are useful for the management of mechanized fertilizers and soil correctives application in coffee plantations.

\section{ACKNOWLEDGEMENTS}

The authors would like to thank the Coordenação de Aperfeiçoamento de Pessoal de Nível Superior (Capes), the Fundação de Amparo à Pesquisa do Estado de Minas Gerais (Fapemig) and the Conselho Nacional de Desenvolvimento Científico e Tecnológico (CNPq) for supporting the development of this study.

\section{REFERENCES}

BAMBI, G. et al. Rural Tourism to Promote Territories along the Ancient Roads of Communication: Case Study of the Rediscovery of the St. Francis's Ways Between Florence and La Verna. European Countryside, 11(3):462-474, 2019.

BARROS, M. M. et al. Performance of a variable-rate distribution system for simultaneous fertilizer application. Revista Brasileira de Engenharia Agrícola e Ambiental, 20(2):188-192, 2016.

CUNHA, J. P. B. et al. Estudo técnico e econômico de diferentes operações mecanizadas na cafeicultura. Coffee Science, 11(1):87-96, 2016.

CUNHA, J. P. B.; SILVA, F. M.; DIAS, R. E. B. A. Eficiência de campo em diferentes operações mecanizadas na cafeicultura. Coffee Science, 11(1):76-86, 2016.

HOJI, M. Administração financeira: Uma abordagem

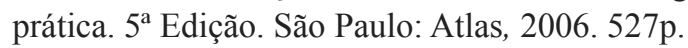

HUNT, D. Farm power and machinery management. 9. ed. Ames: Iowa State University Press, 1995. 363p.

LANNA, G. B. M.; REIS, R. P. Influência da mecanização da colheita na viabilidade econômico-financeira da cafeicultura no sul de Minas Gerais. Coffee Science, 7(2):110-121, 2012.

LOMBARDO, S. et al. Proposal for spaces of agrotechnology co-generation in marginal areas. Atti Della Societa

Toscana Di Scienze Naturali, 125:19-24, 2018.

MIALHE, L. G. Manual de mecanização agrícola. São Paulo: Agronômica Ceres, 1974. 301p.

MOLIN, J. P. et al. Utilização de dados georreferenciados na determinação de parâmetros de desempenho em colheita mecanizada. Engenharia Agrícola, 26(3):759767, 2006.

PELOIA, P. R.; MILAN, M. Proposta de um sistema de medição de desempenho aplicado à mecanização agrícola. Engenharia Agrícola, 30(4):681-691, 2010. 
SANTINATO, F. et al. Análise quali-quantitativa da operação de colheita mecanizada de café em duas safras. Coffee Science, 9(4):495-505, 2014.

SILVA, F. M. et al. Viabilidade técnica e econômica da colheita mecanizada do café. Visão Agrícola, (13):98101, 2013.

SILVEIRA, G. M.; YANAI, K.; KURACHI, S. A. Determinação da eficiência de campo de conjuntos de máquinas convencionais de preparo do solo, semeadura e cultivo1. Revista Brasileira de
Engenharia Agrícola e Ambiental, 10(1):220-224, 2006.

SILVEIRA, G. M.; YANAI, K.; KURACHI, S. A. Influência da velocidade do trator no controle de plantas daninhas, adubação, pulverização da cultura do café. Revista Engenharia na Agricultura, 15(3):250-260, 2007.

SIMÕES, D.; SILVA, M. R.; FENNER, P. T. Desempenho operacional e custos da operação de subsolagem em área de implantação de eucalipto. Bioscience Journal, 27(5):692-700, 2011. 